\title{
The Relationships Among Writing Skills, Writing Anxiety and Metacognitive Awareness
}

\author{
Elif Emine Balta ${ }^{1}$ \\ ${ }^{1}$ Sivas, Turkey \\ Correspondence: Elif Emine Balta, Sivas, Turkey. \\ Received: February 9, 2018 \\ Accepted: March 8, 2018 Online Published: March 22, 2018 \\ doi:10.5539/jel.v7n3p233 \\ URL: https://doi.org/10.5539/jel.v7n3p233
}

\begin{abstract}
The purpose of this study was to investigate the relationships among students' argumentative text writing skills, writing anxiety, and metacognitive awareness. The participants were composed of 375 8th graders in six middle schools in Sivas. Metacognitive Awareness Inventory (B Form) which was adapted in to Turkish by Karakelle \& Saraç (2007) and Writing Anxiety Scale which was developed by Yaman (2010) were used to collect data. The argumentative texts that were gathered from the students were evaluated using the Argumentative Essay Rubric, which was developed within the scope of this study. Descriptive statistics were calculated, Spearman Correlation Analysis, and Kruskal-Wallis Test were applied for analyzing the data. The analyses revealed that the students' argumentative text writing skills were inadequate. It was also determined that students with low writing anxiety were more successful in writing argumentative texts when compared with their counterparts with middle and high anxiety levels. Moreover, slight and positive relationship between argumentative text writing skills and metacognitive awareness, and a significant relationship between writing anxiety and metacognitive awareness were determined. As a result of the study, it can be stated that decreasing students' writing anxiety and increasing their metacognitive awareness will have a positive effect on their argumentative text writing skills.
\end{abstract}

Keywords: argumentative essay, writing anxiety, metacognitive awareness

\section{Introduction}

Individuals effectively satisfy their self-expression needs through their speaking and writing skills. Writing is putting the information that is selected based on goal, method, topic, and limits down on paper by structuring it through some processes such as ordering, classifying, associating, matching, criticizing, estimating, analyzing, synthesizing, and evaluating (Güneş, 2007). In other words, it is the process of retrieval, compilation, election, organization, and reinterpretation of information, which results in writing by considering grammar and spelling. Both a product and process, writing is a personal cognitive activity, and it reflects individual phenomenology. Each act of writing is the writer's action of meaning production. Reading, reflecting, and reviewing are the reflection strategies while editing, drafting, idea generation, word production, translation, and revising are the control strategies that are responsible for meaning production, all of which are used to ensure the meaning production consistent with the writer's goals of writing (Hacker, Keener, \& Kircher, 2009).

Different text types require the use of different thinking ways due to their variation in terms of function and structure. The most distinct feature that distinguishes an argumentative text from others is that it is based on the ground of argument-counterargument (Toulmin, 2003; Andriessen, Chanquoy, \& Coirier, 1999). Argumentative text is a type of text which involves an argument and a counterargument about a topic, where the writer defends his/her argument and tries to explain the irrationality of the counterarguments on logical grounds, and where he/she structures his/her opinions through intellectual skills. The writer tries to persuade reader to think the way he/she does. This effort to convince or prove requires the writer to consider the strong and weak aspects of both arguments in the text (Dilber, 2014). Opinions viewed from different perspectives are grounded on arguments and explained. While the writer presents the proofs and logical grounds about the correctness of his/her argument and the falsity of the counterargument within a cause and effect relationship, he/she makes use of facts, examples, and supporting experiences (Özdemir, 2007; Can, 2006). A sensible and strong argument that is properly organized and supported by proofs from multiple perspectives makes it valid at the same time. A body of research on writing in Turkey focused on argumentative writing skills. The topics involved in these studies were the effects of different strategies and methods on argumentative writing skills (Çakmak, 2013; Dilber, 2014), 
students' argumentative writing skill levels (Gökçe, 2016; Öztürk, 2016; Sis \& Bahşi, 2016), the ways of improving thinking process used in argumentative text by preservice teachers (Gökçe \& Çelebi, 2015), problems experienced by undergraduates during the creation of argumentative texts (Coşkun \& Tiryaki, 2013), the effect of argumentative writing education of critical thinking tendency and writing anxiety (Tiryaki,2011; Çakmak \& Civelek, 2013), the use of argumentative text in teaching Turkish to foreigners (Karabayır \& Derzinevesi, 2015). The most common finding of these studies shows that the students are not successful at writing argumentative texts no matter at what stage they are, and it is required to provide planned and strategic writing education to ensure the success.

Although it is a cognitive process, writing competency is associated with motivation. The low writing motivation is sourced from low writing self-efficacy, low self-regulation, and high writing anxiety (Payne, 2012). In short, writing anxiety is among the affective factors that interrupts or prevents writing process (Blasco, 2016). The unwillingness to write and the existence of disproven statements such as "writers are born not made" and "good writers are creative and inspiring" fuel up the writing anxiety and have an adverse effect on writing skills (Shunk, 2009). As an affective factor, writing anxiety creates stress and worry for students and causes them to avoid or give up writing (Katranc1, 2015; Blasco, 2016). The researchers mostly mentioned the adversities brought by the anxiety. However, it was also expressed that a reasonable level of writing anxiety might encourage students to write. Viewing writing anxiety as an affective reaction to writing, Güneyli (2016) expressed that it would not be true to state that anxiety would influence writing process only negatively.

\subsection{Metacognitive Awareness}

One of the biggest mistakes in education is to focus on what students think rather than how they think (Behrooznia, Hashemi, \& Mahjoobi, 2014). It is necessary to be aware of thinking in order to explore the best way, foresee the possible mistakes, and reach accurate results in thought production and problem solving. The concept of metacognition, which was proposed during 1970s, is addressed at this point.

In the shortest manner, metacognition is described as “thinking about thinking" and knowing what is and isn't known (Serra \& Metcalfe, 2009). In other words, it is defined as one's awareness of its own knowledge and thought and reflection of and controlling these processes (Flavell, 1979; Blakey \& Spence, 1990; Livingston, 2003; Martinez, 2006; Özsoy, 2008; Negretti, 2012). It has two interrelated dimensions called as metacognitive knowledge and metacognitive control (Flavell, 1979). Metacognitive knowledge involves three types of knowledge: declarative knowledge, the knowledge about what to do; procedural knowledge, the knowledge of how to do something; and conditional knowledge, knowledge about when to use a procedure (Karakelle \& Saraç, 2007). Declarative knowledge refers to one's knowledge about its own skills (weak and strong sides). Procedural knowledge addresses one's knowledge about how to follow a procedure, while conditional knowledge involves one's knowledge about when, where, and why the declarative and procedural knowledge is used (Harris, Graham, Brindle, \& Sandme, 2009). Metacognitive control involves the use of metacognitive regulation or strategies. Elaborating, planning, monitoring, and evaluating strategies are used to benefit from metacognitive knowledge when necessary (Karakelle \& Saraç, 2007; Özsoy, 2008). One's awareness of its cognition requires an understanding and control of it. Moreover, metacognitive awareness, which means knowing the strong and weak aspects of thinking, makes it possible to internalize and assimilate the knowledge (Harris et al., 2009; Langford, 2015). The goals of this research are:

1) To determine students' writing skill, metacognitive awareness, and writing anxiety levels,

2) To determine whether there are significant relationships among students' argumentative writing skills, writing anxiety, and metacognitive awareness.

\section{Method}

\subsection{Research Design}

The purpose of this study was to determine the relationships among argumentative writing skills, writing anxiety, and metacognitive awareness. Within this context, relational screening model, which is a research model that aims to determine the presence and/or degree of the shared change between two or more variables, was used in this study (Karasar, 2009).

\subsection{Research Sample}

The participants involved 375 8th graders (165 males, 201 female) studying at six different middle schools in Sivas province during 2016-2017 academic year. They were involved in the study through random sampling technique. 


\subsection{Research Instruments and Procedure}

Writing Anxiety Scale: Writing Anxiety Scale, which was developed by Yaman (2010), was used in this study. As a result of factor analysis, 19 items, which were loaded on one factor and explained the $30.5 \%$ of the variance, were obtained. It was expressed that Chi-square value $\left(x^{2}=557.54, \mathrm{df}=151, \mathrm{p}=0.00\right)$, fit indexes (RMSEA $=.059$, $\mathrm{CFI}=.92, \mathrm{IFI}=.92, \mathrm{GFI}=.93, \mathrm{AGFI}=.91$, and $\mathrm{SRMR}=.050)$, internal consistency coefficient (.80), and item-total correlations (ranged between .30 and .52 ) was satisfactory.

Metacognitive Awareness Scale (B Form): Metacognitive Awareness Scale (Jr. MAI) A and B Forms was developed by Sperling, Howard, Miller, and Murphy (2002) and adapted into Turkish by Karakelle \& Saraç (2007). The B Form is suitable for 6th, 7th, 8th, and 9th graders. It was composed of 18 items under one factor. It was expressed that the correlation value and Cronbach alpha coefficient of the scale was found $.72(\mathrm{~N}=373$, $\mathrm{p}<.01)$ and .80 , respectively. It was also stated that the correlation values ranged from .38 to .60 . The higher scores obtained from the scale indicates higher metacognitive awareness.

Text Writing Form: Seven topics were determined for argumentative texts that would be collected from students. Students' interests and actuality of topics were considered during the determination of topics. Four teachers of Turkish language were asked to review the topics, and two topics were excluded. The options that were provided in the form can be seen below:

Should digital games be prohibited? Why?
Is social media harmful for children? Why?
Is it family or environment that is effective in development of personality? Why?
Is it hardworking or intelligence that makes people successful? Why?
Is a good diet important to be healthy? Why?

The data of this study were collected at three sessions. Metacognitive Awareness Scale (B Form) and Writing Anxiety Scale were distributed in two sessions, each of which lasted 20 minutes. In the last session that lasted for one class hour, the students were asked to write an argumentative text.

\subsection{Data Analysis}

The data obtained from Writing Anxiety Scale and Metacognitive Awareness Scale (B Form) were analyzed using SPSS statistics software. The continuous variables were analyzed using mean, standard deviation, kurtosis, and skewness values, while the discontinuous variables were analyzed using frequency and percentages. The assumptions were tested to decide on which analyses to use. Kolmogorov-Smirnov test was used to test normality since there were more than 50 observations (Field, 2009). Spearman correlation coefficient was estimated to examine the relationship among variables. Kruskal-Wallis $\mathrm{H}$ test was used to examine the significance of the differences in students' writing skills and metacognitive awareness levels in terms of their writing anxiety due to the violence of normality assumptions (Field, 2009; Büyüköztürk, 2009; Kalayc1, 2009). The significance level was determined as .05 for hypothesis tests.

The argumentative texts obtained from participants were scored using Argumentative Writing Evaluation Form, which was developed for this study. The Form was based on primary trait scoring technique. Primary trait scoring technique evaluates the achievement level of a text peculiar to a specific duty by emphasizing the traits of that duty (Lloyd-Jones, 1977; Brown, 2004). Within this context, studies on the structure of argumentative texts were reviewed to determine the primary traits of an argumentative text. Components of argumentative text were examined in these studies (Toulmin, 2003; Aldağ, 2006; Tiryaki, 2011; Nimehchisalem, Mukundan, \& Shameem, 2012; Nussbaum \& Kardash, 2015; Stapleton \& Wu, 2015). As a result of the review, the criteria to be met by students were determined and defined based on "argument-counterargument" primary trait (Ömür \& Erkuş, 2013). The criteria and scoring were given to an academic working at Department of Turkish Education and four teachers of Turkish language working at middle schools in Sivas to receive their opinions. The criteria definitions were revised and the evaluation form was finalized. As a result, seven criteria, which were "Argument, Counterargument, Supporting Argument, Refuting Counterargument, Evidencing, Exemplification, and Concluding" were involved. Each criterion was scored between 0 and 4 . The texts were evaluated by two teachers of Turkish language in addition to the author, and the mean score of three evaluators were estimated for each text. 


\section{Results}

The descriptive statistics regarding students' argumentative writing scores and metacognitive awareness levels are presented in Table 1.

Table 1. Descriptive statistics of Writing Argumentative Essay (WAE) and Metacognitive Awareness Inventory (MAI)

\begin{tabular}{lllllll}
\hline & $\mathrm{N}$ & Range & $\mathrm{X}$ & Std. Dev & Skewness & Kurtosis \\
\hline WAE & 375 & 45 & 18,84 & 7,57 & 1,56 & 2,77 \\
MAI & 375 & 61 & 70,18 & 9,88 & $-0,73$ & 0,90 \\
\hline
\end{tabular}

As can be seen in Table 1, students' argumentative writing mean score was 18.84 while the standard deviation was 7.57. When the distribution of writing scores was examined, it was observed that the distribution was right skewed and had a sharp peak. The low mean score and right skewed distribution showed that the students had low argumentative writing scores. The small standard deviation and sharp peaked distribution demonstrated that the students were similar in terms of argumentative writing skills (Field, 2009). When the descriptive statistics of students' metacognitive awareness levels were examined, it was observed that the mean score was 70.18 and standard deviation was 9.88. The distribution was mildly left skewed and was normal in terms of kurtosis (Field, 2009). The high mean and structure of distribution indicated normal distribution. Accordingly, it can be expressed that students' metacognitive awareness levels were high. The distribution of students' writing skills and metacognitive awareness levels can be seen in Figure 1.
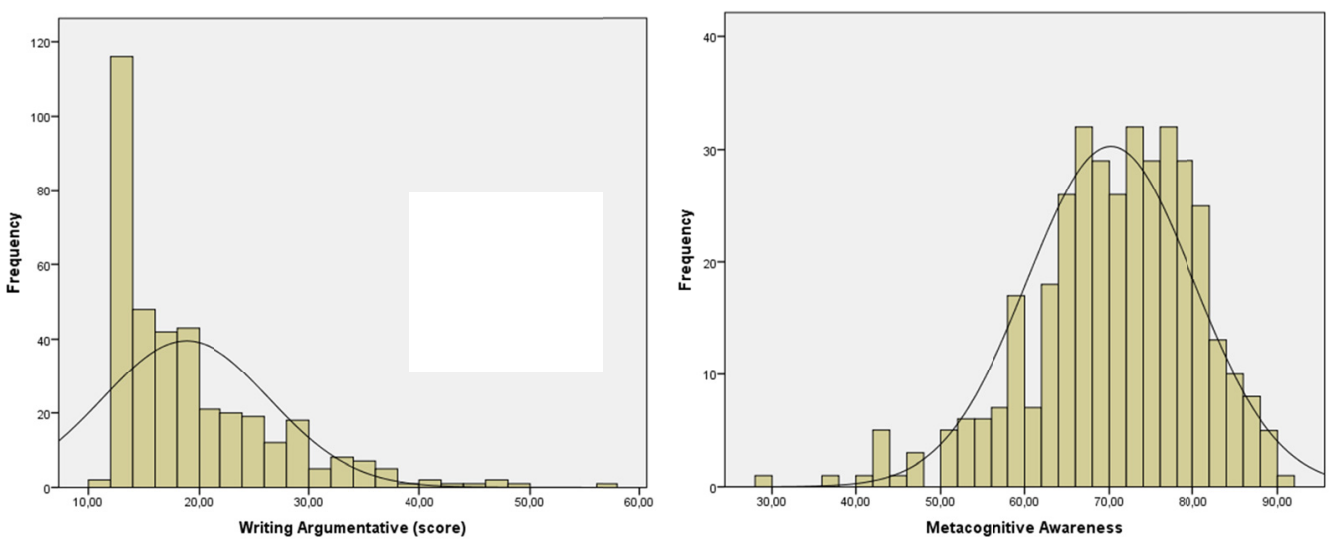

Figure 1. Histograms of WAE and MAI

Students' writing anxiety was categorized as low, middle, and high. When the students' writing anxiety was examined in terms of frequency and percentage, it was observed that $4.8 \%(\mathrm{f}=18)$ had low, $70.1 \%(\mathrm{f}=263)$ had middle, and $25.1 \%$ ( $\mathrm{f}=94$ ) had high levels of writing anxiety.

The relationship between students' argumentative writing scores and metacognitive awareness levels was examined. Pearson correlation coefficient was planned to be used to examine this relationship since both variables were continuous. Thus, normality assumption was tested (Field, 2009). Kolmogorov-Smirnov test results can be seen in Table 2 .

Table 2. Results of the Kolmogorov-Smirnov

\begin{tabular}{llll}
\hline & Kolmogorov-Smirnov & df & $\mathrm{p}$ \\
\hline WAE & 0,178 & 375 & 0,000 \\
MAI & 0,065 & 375 & 0,000 \\
\hline
\end{tabular}


As can be seen in Table 2, neither of variables met the normality assumption. Therefore, Spearman coefficient was used. The Spearman correlation coefficient between writing scores and metacognitive awareness was $r=0.24$. This value indicates a positive and weak relationship (Kalayc1, 2009).

The findings regarding the differences in students' writing scores and metacognitive awareness in terms of writing anxiety can be seen in Table 3 .

Table 3. Descriptive statistics of WAE and MAI for writing anxiety

\begin{tabular}{llllll}
\hline & \multicolumn{3}{c}{ WAE } & MAI \\
\hline Writing Anxiety & $\mathrm{N}$ & $\mathrm{X}$ & Std. Dev & $\mathrm{X}$ & Std. Dev \\
Low & 18 & 24,00 & 8,56 & 76,44 & 7,98 \\
Middle & 263 & 18,95 & 7,74 & 71,65 & 8,82 \\
High & 94 & 17,54 & 6,41 & 64,89 & 10,94 \\
\hline
\end{tabular}

In Table 3, it can be seen that students' argumentative writing scores and metacognitive awareness differed in terms of anxiety levels. Variance analysis was conducted to determine the significance of difference in students' argumentative writing scores in terms of anxiety levels. Kruskal-Wallis $\mathrm{H}$ test was used since the number of students with low anxiety level was less than 30 and the distribution of writing scores and metacognitive awareness wasn't normal (Field, 2009; Büyüköztürk, 2009). Kruskal-Wallis H test results can be seen in Table 4.

Table 4. Results of Kruskal-Wallis H Test

\begin{tabular}{|c|c|c|c|c|c|c|c|c|}
\hline \multicolumn{9}{|c|}{ WAE } \\
\hline Writing Anxiety & $\mathrm{N}$ & $\mathrm{X}$ & Std. Dev & Mean Rank & Chi-Square & df & $\mathrm{p}$ & Difference \\
\hline Low & 18 & 24,00 & 8,56 & 264,22 & 11,89 & 2 & 0,003 & $1-2 ; 1-3$ \\
\hline Middle & 263 & 18,95 & 7,74 & 189,49 & & & & \\
\hline High & 94 & 17,54 & 6,41 & 169,24 & & & & \\
\hline \multicolumn{9}{|c|}{ MAI } \\
\hline Writing Anxiety & $\mathrm{N}$ & $\mathrm{X}$ & Std. Dev & Mean Rank & Chi-Square & df & $\mathrm{p}$ & \\
\hline Low & 18 & 76,44 & 7,98 & 265,25 & 35,02 & 2 & 0,000 & $1-2 ; 1-3 ; 2-3$ \\
\hline Middle & 263 & 71,65 & 8,82 & 201,38 & & & & \\
\hline High & 94 & 64,89 & 10,94 & 135,77 & & & & \\
\hline
\end{tabular}

As a result of the analysis, the differences between students' writing scores in terms of writing anxiety were observed to be significant $(\mathrm{p}<.05)$. The results showed that the difference was significant between at least two groups (Kalayc1, 2009). Mann-Whitney U test was conducted to determine which groups were significantly differentiated from others (Büyüköztürk, 2009). The findings showed that students with low anxiety level had significantly higher writing scores than students with middle and high anxiety levels. The difference in writing scores between students with middle and high anxiety was not significant.

Table 4 also showed that there were significant differences in students' metacognitive awareness in terms of writing anxiety $(p<.05)$. The findings showed that students with low anxiety level had significantly higher metacognitive awareness than students with middle and high anxiety levels. Moreover, the difference between the metacognitive awareness of students with middle level and high levels was found to be significant. The findings suggested that the lower their anxiety was, the higher their metacognitive awareness was. Students' writing anxiety, writing skills, and metacognitive awareness can be viewed in Figure 2. 

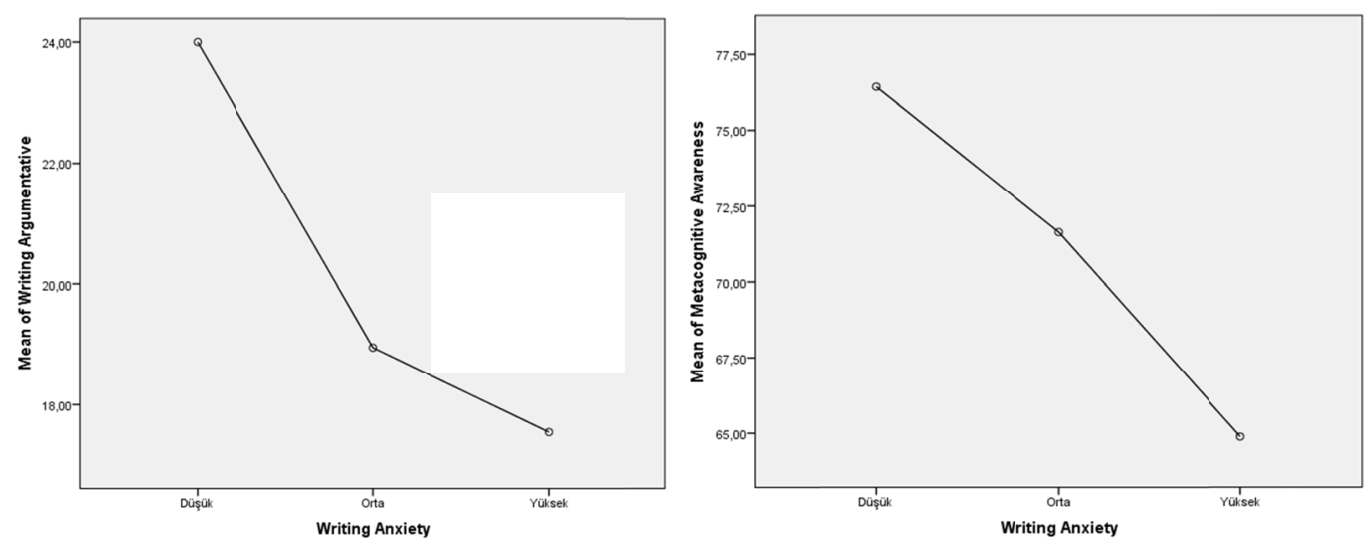

Figure 2. Histograms of WAE, MAI and writing anxiety

\section{Discussion}

The biggest reason why it is difficult to improve writing skills is that it is a cognitive activity carried out, repeated, and regulated in a period. Within this context, it is important to be aware of factors that could have an effect on writing skills. In this study, it was intended to investigate the relationship of argumentative writing skill with metacognitive awareness and writing anxiety.

Within the scope of the study, students' argumentative texts were scored, and it was revealed that 8 th graders' argumentative writing skills were low. Studies on writing skills in Turkey underlines that writing skills weren't at a sufficient level. In a study conducted by Gökçe \& Sis (2017), it was found that students' argumentative writing skills were at a middle level and their text consistency was low in general. Arıc1 \& Ungan (2008) found that the majority of middle school students experienced problems with gathering ideas, organizing, creating the main idea, and misspelling. Kurudayığlu \& Yılmaz (2014) revealed that the persuvasive texts written by preservice Turkish teachers involved problems in all units except for the thesis part. The findings were consistent with the results of studies conducted by Bağc1 (2010) on preservice Turkish teachers, by Coşkun \& Tiryaki (2013) on undergraduates, and Sis \& Bahşi (2016) and Deniz (2017) on middle school students, which revealed incompetency in writing skills. As expressed also by Ungan (2007), these findings confirmed that the importance of writing education hasn't been understood well in Turkey.

Another finding of this study was the relationship between argumentative writing skills and writing anxiety. As a result of analyses, it was found that students with low writing anxiety were more successful in argumentative writing than their counterparts with middle or high writing anxiety. Having low writing anxiety results in more success in written expression compared with having high writing anxiety. The negative effect of middle and high level of writing anxiety on writing skill is consistent with the findings of a study conducted by Zorbaz (2010). A body of research evidenced the negative relationship between writing anxiety and writing skill in native or foreign language (Daly, 1978; Kim, 2006). However, Tiryaki (2011) was unable to find a significant relationship between undergraduates' argumentative writing skills and writing anxiety.

The metacognitive awareness of students was found to be high. It was also found that there was a significant and weak relationship between students' argumentative writing skills and metacognitive awareness. A similar result was found by Tiryaki (2011), who revealed a weak relationship between argumentative writing success and critical thinking skills. Metacognitive awareness is defined as the most important trait of an effective writer (El Hindi, 1996). Although it wasn't strong, this study revealed a significant relationship between two variables. Similarly, Negretti (2012) found that metacognitive awareness improved students' development of writing. Karatay (2011) emphasized that students' incompetency in cognitive thinking process is one of the factors that adversely affect their writing success.

In this study, it was found that as the students' metacognitive awareness increased, their writing anxiety decreased. Determining that metacognitive awareness and low writing anxiety facilitated students' use of writing strategies, Stewart, Seifert, \& Rolheiser (2015) underlined the link between anxiety and metacognition. Blasco (2016) found a negative relationship between metacognitive writing strategies and writing anxiety. 
As the other studies in Turkey did, the findings of this study underlined the necessity to place emphasis on writing education and make it functional in Turkish curriculum. Considering the low writing anxiety would improve writing skills, it is important for teachers to encourage students and create a classroom environment that would motivate students to write. The existence of a relationship between metacognitive awareness and writing skills means that each cognitive skill can have an effect on one another. Thus, it is recommended for teachers to train their students about the use of metacognitive strategies during writing activities and include the writing process to evaluation in addition to product.

In this study, students' argumentative writing performance was involved and other text types were excluded. Moreover, the study was limited by determining the relationships between students' argumentative writing skills, writing anxiety and metacognitive awareness.

\section{References}

Aldağ, H. (2006). Toulmin tartışma modeli. Çukurova Üniversitesi Sosyal Bilimler Enstitüsü Dergisi, 15(1).

Andriessen, J. E. B., Chanquoy, L., \& Coirier, P. (1999). From planning to translating: The specificity of argumentative writing (pp. 1-28). Amsterdam: Amsterdam University Press.

Arıcı, A. F., \& Ungan, S. (2008). İlköğretim ikinci kademe öğrencilerinin yazılı anlatım çalışmalarının bazı yönlerden değerlendirilmesi. Dumlupınar Üniversitesi Sosyal Bilimler Dergisi, 20, 319-327.

Bağcı, H. (2010). Türkçe öğretmeni adaylarının yazılı anlatım yeterlilik düzeyleri. İnönü Üniversitesi Eğitim Fakültesi Dergisi, 11(2), 45-68.

Behrooznia, S., Hashemi, M. R., \& Mohaghegh M. F. (2014). A critical look into Iranian EFL university students' critical thinking and argumentative writing. Iranian Journal of Applied Linguistics, 17(1), 71-92.

Berk, R. R., \& Ünal, E. (2017). Comparison of writing anxiety and writing dispositions of sixth, seventh and eighth grade students. International Journal of Instruction, 10(1), 237-254. https://doi.org/10.12973/iji.2017.10115a

Blakey, E., \& Spence, S. (1990). Developing metacognition. Retrieved from https://files.eric.ed.gov/fulltext/ED327218.pdf

Blasco, J. A. (2016). The relationship between writing anxiety, writing self-efficacy, and Spanish EFL students' use of metacognitive writing strategies: A case study. Journal of English Studies, 14, 7-45. http://dx.doi.org/10.18172/jes.3069

Brown, H. D. (2004). Language assessment: Principles and classroom practices. Boston: Allyn \& Bacon.

Büyüköztürk, Ş. (2009). Sosyal bilimler için veri analizi el kitabı. Ankara: Pegem Akademi.

Çakmak, E. (2013). Metin yapısı öğretiminin öğretmen adaylarının tartışmacı yazma becerilerine etkisi. Eğitimde Kuram ve Uygulama, 9(4), 379-389.

Çakmak, E., \& Civelek, F. (2013). Tartı̧̧macı yazma eğitiminin öğretmen adaylarının eleştirel düşünme eğilimleri ve yazma kaygılarına etkisi. Gazi Üniversitesi Gazi Eğitim Fakültesi Dergisi, 33(2).

Can, H. (2006). An analysis of freshman year university students' argumentative essays (Unpublished master's thesis). Boğaziçi University, İstanbul.

Coşkun, E., \& Tiryaki, E. N. (2013). Üniversite öğrencilerinin tartışmacı metin yapısını oluşturmadaki sorunları. Adlyaman Üniversitesi Sosyal Bilimler Enstitüsü Dergisi, 2013(11). https://doi.org/10.14520/adyusbd.487

Daly, J. A. (1978). Writing apprehension and writing competency. The Journal of Educational Research, 72(1), 10-14. https://doi.org/10.1080/00220671.1978.10885110

Deniz, E. (2017). Yedinci sinıf ögrencilerinin dil bilgisi, kelime bilgisi ve okuduğunu anlama düzeyleri ile yazma becerileri arasındaki ilişki (Yayımlanmamış doktora tezi). İnönü Üniversitesi, Malatya.

Dilber, Ç. N. (2014). Öz düzenlemeli strateji gelişimi ögretim modelinin ortaokul öğrencilerinin ürettikleri tartışmacı metinlere etkisi (Yayımlanmamış doktora tezi), Ankara Üniversitesi, Ankara.

El-Hindi, A. E. (1996). Enhancing metacognitive awareness of college learners. Reading Horizons, 36(3), 2.

Field, A. (2009). Discovering statistics using SPSS. London: Sage.

Flavell, J. H. (1979). Metacognitive and cognitive monitoring: A new area of cognitive developmental inquiry. American Psychologyst, 34, 906-911. https://doi.org/10.1037/0003-066X.34.10.906 
Gökçe, B. (2016). Sekizinci sınıf öğrencilerinin tartışmacı metin yazma becerileri ile bu becerilere ilişkin ögrrenci ve ögrretmen görüşleri (Yayınlanmamış doktora tezi), İnönü Üniversitesi, Malatya.

Gökçe, B., \& Çelebi, S. (2015). Fen bilgisi öğretmeni adaylarının tartışmacı metinlerinde düşünceyi geliştirme yolları. Recep Tayyip Erdoğan Üniversitesi Sosyal Bilimler Dergisi, 1, 11-30.

Gökçe, B., \& Sis, N. (2017). Sekizinci sınıf öğrencilerinin tartışmacı metin yazma becerilerinin çeşitli değişkenler açısından incelenmesi. International Journal of Language Academy, 5(8), 143-168 http://dx.doi.org/10.18033/ijla.3832

Güneş, F. (2007). Türkçe öğretimi ve zihinsel yapılandırma. Ankara: Nobel Yayın Dağıtım.

Güneyli, A. (2016). Kıbrısl Türk öğrencilerin yazma kaygısı düzeylerinin incelenmesi. Eğitim ve Bilim, 41(183). http://dx.doi.org/10.15390/EB.2016.4503

Hacker, D. J., Keener, M. C., \& Kircher, J. C. (2009). Writing is applied metacognition. In D. J. Hacker, J. Dunlosky, \& A. C. Graesser (Eds.), Handbook of metacognition in education (pp. 154-172). New York, NY: Routledge

Harris, K. R., Graham, S., Brindle, M., \& Sandmel, K. (2009). In D. J. Hacker, J. Dunlosky, \& A. C. Graesser (Eds.), Handbook of metacognition in education (pp. 131-153). New York, NY: Routledge.

Kalaycı, Ş. (2009). SPSS uygulamaları. Çok değişkenli istatistik teknikleri. Ankara: Asil Yayın Dağıtım.

Karabayır, M., \& Derzinevesi, H. (2015). Yabancılara Türkçe öğretiminde tartışmacı metinlerin kullanımı. Avrasya Incelemeleri Dergisi, 4(1), 104-120.

Karakelle, S., \& Saraç, S. (2007). Çocuklar için üstbilişsel farkındalık ölçeği (ÜBFÖ-Ç) A ve B formları: Geçerlik ve güvenirlik çalışması. Türk Psikoloji Yazıları, 10(20), 87-103.

Karatay, H. (2011). 4+1 planlı yazma ve değerlendirme modelinin öğretmen adaylarının yazılı anlatım tutumlarını ve yazma becerilerini geliştirmeye etkisi. Turkish Studies, 6(3), 1029-1047.

Kim, K. J. (2006). Writing apprehension and writing achievement of Korean EFL college students. English Teaching-Anseonggun, 61(1), 135.

Kurudayığlu, M., \& Yılmaz, E. (2014). Türkçe öğretmeni adaylarının oluşturdukları ikna edici metinlerin yapı açısından incelenmesi. Okuma Yazma Eğitimi Araştırmaları, 2(1), 12-21.

Langford, S. (2015). Reflecting on revision: Student reflection and metacognitive awareness in the writing process. Studies in Teaching 2015 Research Digest, 61.

Lloyd-Jones, R. (1977). Primary trait scoring. Evaluating Writing: Describing, Measuring, Judging, 33-66. Retrieved from https://files.eric.ed.gov/fulltext/ED143020.pdf\#page $=43$

Martinez, M. E. (2006). What is metacognition? Phi delta Kappan, 87(9), 696-699. https://doi.org/10.1177/003172170608700916

Negretti, R. (2012). Metacognition in student academic writing: A longitudinal study of metacognitive awareness and its relation to task perception, self-regulation, and evaluation of performance. Written Communication, 29(2), 142-179. http://dx.doi.org/10.1177/0741088312438529

Nimehchisalem, V., Mukundan, J., \& Shameem, R. G. (2012). Developing an argumentative writing scale. Pertanika Journal of Social Sciences and Humanities (JSSH), 20, 185-204.

Nussbaum, E. M., Kardash, C. M., \& Graham, S. E. (2005). The effects of goal instructions and text on the generation of counterarguments during writing. Journal of Educational Psychology, 97(2), 157. https://doi.org/10.1037/0022-0663.97.2.157

Ömür, S., \& Erkuş, A. (2013). Dereceli puanlama anahtarıyla, genel izlenimle ve ikili karşılaştırmalar yöntemiyle yapılan değerlendirmelerin karşılaştırılması. Hacettepe Üniversitesi Eğitim Fakültesi Dergisi, 28(28-2).

Özdemir, E. (2007). Yazınsal türler. Ankara: Bilgi Yayınevi

Özsoy, G. (2008). Üstbiliş. Türk Eğitim Bilimleri Dergisi, 6(4), 713-740.

Öztürk, D. (2016). Öğretmen adaylarının tartışmacı metin yazma becerileri üzerine bir araştırma (Yayınlanmamış yüksek lisans tezi). İnönü Üniversitesi, Malatya.

Payne, A. R. (2012). Development of the academic writing motivation questionnaire (Doctoral dissertation). University of Georgia. Retrieved from https://getd.libs.uga.edu/pdfs/payne_ashley_r_201212_ma.pdf 
Serra, M. J., \& Metcalfe, J. (2009). Effective implementation of metacognition. In D. J. Hacker, J. Dunlosky, \& A. C. Graesser (Eds.), Handbook of metacognition in education (pp. 278-298). New York, NY: Routledge.

Sis, N., \& Bahşi, N. (2016). Sekizinci sınıf öğrencilerinin tartışmacı metin yazma becerileri üzerine bir araştırma. Turkish Studies, 11(3), 2025-2042. http://dx.doi.org/10.7827/TurkishStudies

Stapleton, P., \& Wu, Y. A. (2015). Assessing the quality of arguments in students' persuasive writing: A case study analyzing the relationship between surface structure and substance. Journal of English for Academic Purposes, 17, 12-23. https://doi.org/10.1016/j.jeap.2014.11.006

Stewart, G., Seifert, T. A., \& Rolheiser, C. (2015). Anxiety and self-efficacy's relationship with undergraduate students' perceptions of the use of metacognitive writing strategies. The Canadian Journal for the Scholarship of Teaching and Learning, 6(1), 4. http://dx.doi.org/10.5206/cjsotl-rcacea.2015.1.4

Tiryaki, E. N. (2011). Üniversite öğrencilerinin tartışmacı metin yazma becerileri ile yazma kaygısı ve eleştirel düşünme becerileri (Yayımlanmamış yüksek lisans tezi). Mustafa Kemal Üniversitesi, Hatay.

Toulmin, S. (2003). The uses of argument (2nd ed.). Cambridge University Press. https://doi.org/10.1017/CBO9780511840005

Ungan, S. (2007). Yazma becerisinin geliştirilmesi ve önemi. Erciyes Üniversitesi Sosyal Bilimler Dergisi, 23, 461-472.

Yaman, H. (2010). Türk öğrencilerinin yazma kaygısı: Ölçek geliştirme ve çeşitli değişkenler açısından yordama çalı̧̧ması. International Online Journal of Educational Sciences, 2(1).

Zorbaz, K. Z. (2010). İlköğretim okulu öğrencilerinin yazma kaygı ve tutukluğunun yazılı anlatım becerileriyle ilişkisi (Yayımlanmamış doktora tezi). Gazi Üniversitesi Ankara.

\section{Copyrights}

Copyright for this article is retained by the author(s), with first publication rights granted to the journal.

This is an open-access article distributed under the terms and conditions of the Creative Commons Attribution license (http://creativecommons.org/licenses/by/4.0/). 